\title{
THE EXAMINATION AND ASSESSMENT OF WINERY BUSINESS AND CONTRIBUTION TO THE DEVELOPMENT OF WINE TOURISM OF SERBIA
}

\author{
Nikica Radović ${ }^{1}$, Snežana Milićević ${ }^{2}$ \\ *Corresponding author E-mail: nradovic@singidunum.ac.rs
}

A R T I C LE IN F O

Original Article

Received: 11 August 2020

Accepted: 09 December 2020

doi:10.5937/ekoPolj2004103R

UDC 339:663.2]:[338.4853:63(497.11)

\section{Keywords:}

business excellence assessment, BEX model, wineries, wine tourism, Serbia

JEL: M21, G30, Q14, L66

\begin{abstract}
A B S T R A C T
The tradition of winemaking on the territory of Serbia dates back to ancient times. Today the activities related to wine production are on the rise, as is the number of wineries, and they participate in the valorization of wine tourism activities as an important Serbian tourist product. The aim of this paper is to assess the business excellence of wine producers in Serbia via the application of BEX model while establishing a correlation with the data on the promotion of wine tourism activities on the analyzed wineries' websites. The attained research results indicate a decrease in the BEX index in 2018 in comparison with the values from 2017 and are within the parameters for good values. However, there is no correlation between the performance of wineries and the promotion of wine tourism on their websites.
\end{abstract}

(C) 2020 EA. All rights reserved.

\section{Introduction}

The quality of business process realization and the business success of companies both depend on risk exposure and appropriate risk management (Regester, Larkin, 1997). According to Stanišić et al. (2017) what is especially reflected in the success of subjects in the economy is extensive exposure to business risks. It is important to bear in mind the significance of the correct choice of business model in order to prevent a negative business result, i.e. business loss (Berk et al., 2012). Among a great number of models for examining and assessing business success the most commonly used models are the Altman model, the Kraliček DF, the Quick Test model, the Zmijewski model, and

1 Nikica Radović, PhD, Assistant Professor, Singidunum University, Faculty of Tourism and Hospitality Management, Danijelova Street 32, 11000 Belgrade, Republic of Serbia, Phone:+381113094048, E-mail: nradovic@singidunum.ac.rs, ORCID ID (https://orcid. org/0000-0001-5415-6746)

2 Snežana Milićević, PhD, Associate Professor, University of Kragujevac, Faculty of Hotel Management and Tourism in Vrnjačka Banja, Vojvođanska Street 5A, 36210 Vrnjačka Banja, Republic of Serbia, Phone: +38163621011, E-mail: snezana.milicevic@ kg.ac.rs, ORCID ID (https://orcid.org/0000-0002-1972-9585) 
the BEX model. Present authors have opted to utilize the BEX model for the purposes of this paper, which is designed for the Croatian market (Belak and Aljinović-Barać, 2008), but is also applicable to economies in the region. Therefore, it is possible to conduct business performance analysis of businesses from Serbia.

The subject of research in this paper is to examine and assess the business success of wine producers using a sample of 50 wineries in Serbia. The analysis and data processing is based upon collected, compiled and processed values from financial reports of the analyzed sample of companies for the business years 2017 and 2018. Several authors have applied in their research the analysis of business excellence of commercial subjects via the BEX model (Rajin et al., 2016; Knežević et al., 2014; Alihodžić, Džafić, 2012; Bubić, Hajnrih, 2012; Belak et al., 2011; Belak, AljinovićBarać, 2008) in different commercial areas. At the same time, this paper includes a correlation analysis of the existence of wine tourism activities promotion impact on the wineries' websites and business success calculated by the BEX model. In this regard, there is a research question whether wineries that promote wine tourism activities on their websites have a better rank of business success in accordance with the values of the BEX model than wineries that do not promote wine tourism activities on their website but implement them, which is confirmed in a survey at the Wine Fair.

According to the on-line statistical data of the International Organization of Vine and Wine, the entire world produced in the year 2017 a total of 248,749,000 hl of wine, and in the year 2018 a total of 293,562,000 hl of wine. The wine production data in Serbia show that in the year 2017 a total of 736,000 hl of wine were produced, and in the year 2018 a total of $665,000 \mathrm{hl}$ of wine (www.oiv.int). Bearing in mind the favorable geographical position and climate conditions, along with the factors of topography, terrain inclination and soil composition specific for the territory of Serbia, the possibilities for growing vine and making wine are numerous. The number of wineries in the territory of Serbia is rising, which poses a challenge for marketing experts who create positioning strategies directed at Serbian consumers (Kuzmanović \& Makajić-Nikolić, 2020). The current transformations of the agricultural sector have imposed new paradigms in using the land resources (Popescu et al., 2017). Crops production represents an important activity for land exploitation (Vasilescu et al., 2010). The reduction in the total produced amount of wine is affected by risks reflected in the variations in annual yields, i.e. the grape crop, which is itself impacted by various natural factors.

The aim of this research is reflected in the analysis of business performance of wineries that valorize wine tourism activities and promote the same on their websites. The results of this research have a scientific and practical contribution. The scientific contribution is reflected in the pioneering endeavor of researching the success of the winery business in relation to promotional activities on their websites. This research gave an assessment of the current situation and recommendations for future business. The specific practical contribution is reflected in the possibilities of using the research results, both by wineries and stakeholders, in order to design certain promotional policies that would contribute to the improvement of winery operations and the development of wine tourism in Serbia. 


\section{Research background}

According to the results of paleontological examinations, vine can be found in prehistoric layers of soil, in the Younger Stone Age, in the Bronze Age, in the Iron Age, and covering vast expanses of land. It was able to cover such a great expanse of land owing to the birds which fed on the fruit and carried the seed (Avramov, 2010).It is generally accepted that the first vineyards were built around $6000 \mathrm{BC}$, north of the Caucasus, in what is now Georgia and Armenia (Despotović, 2012). In many archaeological localities special silver vessels were found containing vine coils. The long tradition of wine production was also confirmed in research in localities from the Roman Empire period where artifacts serving as wine vessels were discovered (Pavlović, 2007).

Viticulture and winemaking in the territory of Serbia have a long tradition as well. The exact time of the beginnings of wine production in Serbia is not known, but it is presumed that the history of winemaking in Serbia exceeds a millennium (Vlahović et al., 2008). It is thought that one of the Roman emperors, Marcus Aurelius Probus, planted the first vines in the space of Fruška gora and in the vicinity of Smederevo. Great devotees of viticulture and winemaking also included the rulers in the dynasties Nemanjić, Hrebeljanović and Branković who expanded the vineyards on Fruška gora and those around Smederevo and Vršac. Emperor Dušan had large vineyards and, in the vicinity of Prizren, the court wine cellar with a $25 \mathrm{~km}$ long ceramic vineduct delivering wine straight from the vineyards and cellars in the surroundings of Velika Hoča. As a patron of viticulture and winemaking, Emperor Dušan established the Law on Wine which determined the rules of wine production, trade, and quality control. Medieval times in Serbia see an advancement and expansion in viticulture. Despot Stefan Lazarević, in the period of moving the capital city from Kruševac to Belgrade, also formed vineyard plantations in the vicinity of Belgrade, creating the then wellknown Ritopek vineyards (Jakšić et al., 2015). However, the arrival of Turks to these parts stemmed the development, and even led to a decrease and halt in winemaking in the territory of today's Serbia, bearing in mind the religious tenets written in the Kur'an, as well as the directives to uproot vineyards. In this period, the production of wine was preserved owing to monasteries within which traditional winemaking was continued (Pivac, 2012). In the XIX century the vines in the territories of France and the Austro-Hungarian Empire became affected by phylloxera transferred in seedlings from American spaces which led to the devastation of a large number of vineyards (Ivanišević et al., 2015). This is when the production of grapes and wine was advanced in the spaces of today's Central Serbia, and Serbian wines makes their way into the European market. At the beginning of the XX century owing to the efforts of king Petar I Karađorđević and prince Aleksandar there were advancements in viticulture and winemaking in Serbia, and they personally grew large vineyards in the spaces of Oplenac and Topola, which in 1903 resulted in the formation of the Venčac vineyard cooperative, as one of the largest wineries in the Balkans (Pivac, 2012).

At the end of the Second World War, the renewal of the state began, as well as the revitalization and renewal of vineyards. In accordance with the economic and political 
ideas of the time, cooperatives, large state estates and large wineries (Navip, Rubin, Vino župa) were established. In that period, individual wine production was neglected, which leads to the interruption of the production tradition within family farms. The main goal of restructuring agriculture follows the old requirements in the field regarding the transformation and modernization of the agricultural sector and food industry (Vasile et al., 2017). After what was perhaps the most difficult period of crisis in the history of Serbian viticulture, towards the end of the XX century, which saw the clearings of plots, the disappearance of large vineyard and winery complexes, an altogether dismal state, viticulture and winemaking in Serbia experienced important transformations, modernization and an overall positive forward movement. This represented a significant step towards nearing European standards and the practices of countries with good results in this area (Ivanišević et al., 2015). Today in Serbia, the revival in viticulture was instigated owing to the interest and initiative of winoholics and enthusiasts. An intensive growth in new vine plots can be noticed, utilizing contemporary technologies of artificial intelligence in the processes of growth, processing vine, and producing grapes. It is characterized by the introduction of high quality, selected and certified plots with the introduction of organic growth of grapes and production of wine (Jakšić et al., 2015). Also, economic efficiency is slightly higher in organic system compared to conventional (Vasile et al., 2015).

Bearing in mind the favorable geographical position and climate conditions, as well as the effects of topographic factors, terrain inclination and soil composition specific to Serbian spaces, the possibilities for viticulture and winemaking are broad. Three vineyard regions were established in the vineyard regionalization of territories in Serbia (the Vojvodina region, the region of Central Serbia and the region of Kosovo and Metohija), within which there are 22 sub-regions with 77 vineyards in several vineyard oases (Jakšić et al., 2019).

Wines from the spaces of the New World ${ }^{3}$ emerged into the world market in the 1990s with acceptable pricing (Vlahović et al., 2017), but also satisfying the expectations of consumers in the younger population. Simultaneously, an initiative with the aim of defending the culture and tradition of producing and consuming wine were started in the countries which are traditionally the greatest European producers of wine. The instigators of the initiative are small/family wineries, and their aim was to stop globalization in wine production, and also revive the practice of wine consumption which was fully suppressed in certain parts of Europe along with modernization in food preparation (Darnay, 2016).

According to on-line data from the International Organisation of Vine and Wine in the year 2017 in the world 7,425,122 ha of soil was covered in vine plantations, and in the year 2018 the area covered was 7,445,129 ha. In Europe, whose spaces contain the countries which are numbered among the greater winemakers in the world (Italy,

3 The countries of the New World include the countries of North and South America, Australia, New Zealand, South Africa 
France, Spain) in the year 2017 there were 3,684,895 ha of soil under vineyards, and in the year 2018 the area covered was 3,690,813 ha. These data indicate an increase in activities to advance winemaking as a commercial branch on the global level.

In Serbia, according to the data from the Statistical Yearlybook of the Statistical Office of the Republic of Serbia for 2018, there was an increase in space units under vines, or put more precisely, in 2017 there were 21,201 ha, and in 2018 there were 21,328 ha. The age structure of vineyards according to the data from the Vineyard Register is such that vineyards aged between 10 and 19 years dominate $(30 \%)$, followed by vineyards aged 4 to 9 years $(22.10 \%)$. Vineyards aged 20 to 29 years account for $17.04 \%, 30$ to 39 years $14.23 \%$, over 40 years of age $11.75 \%$, and the smallest amount of space, $5.09 \%$, is covered by vineyards up to 3 years of age (Figure 1) (Jakšić et al., 2019).

Figure 1. Vineyards according to age groups of plots

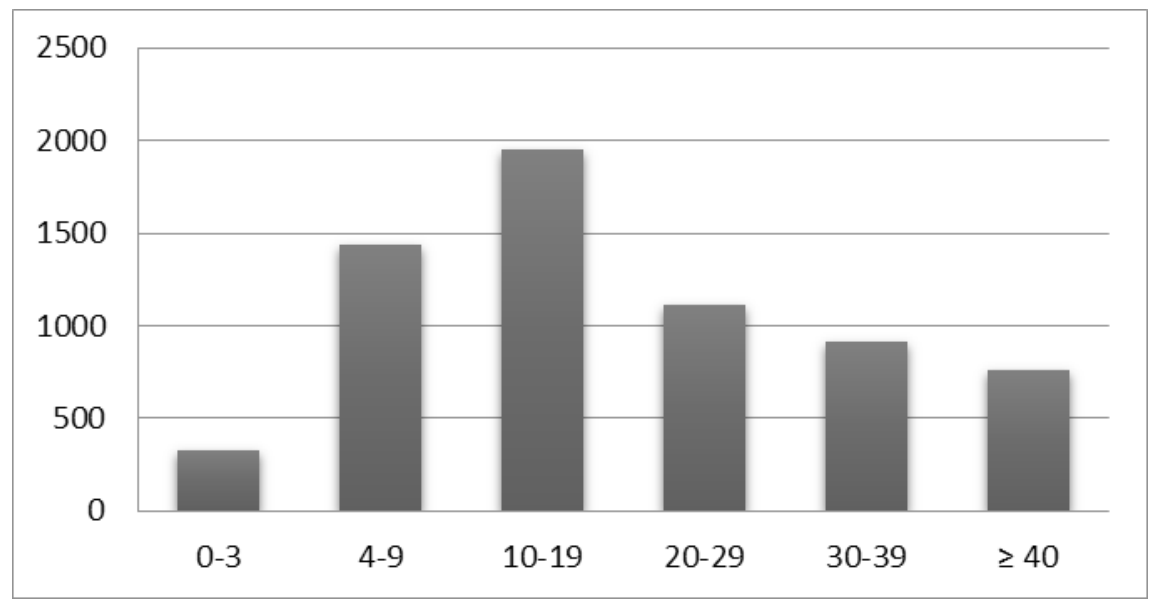

Source: Jakšić et al., 2019, p. 103.

Although there is great potential for viticulture, the economic crisis and loss of market during the 1990s led to a great reduction in the areas covered in vines compared to the preceding period. According to the Strategy for Agriculture and Rural Development of the Republic of Serbia for the period 2014-2024 the areas under vineyards are characterized by a significant fragmentation of allotments, as the average size of vineyards in Serbia is only $0.28 \mathrm{ha}$, and this fragmented structure of the plots considerably increases the overall expenses of grape production (Gazette of the RS 85/2014, p.12).

The Ministry of Agriculture, Forestry and Water Management of the Republic of Serbia has announced a public call for incentives for investments in the wine production sector for 2020. The subject of incentives in accordance with the Ordinance and the Public Invitation are eligible investments and costs in the wine production sector related to construction winery facilities, general cost and/or purchase of new equipment, devices and machines, in operation wine production. The maximum amounts of incentives for each type of incentive are: 
1) for investments in the construction of winery facilities - 30,000,000 RSD;

2) for the purchase of new equipment, devices and machines in the function of wine production - 10,000,000 RSD;

3) for general expenses - 1,000,000 RSD.

The highest total amount of incentives that an incentive user can receive in one calendar year is 41,000,000 RSD (www.uap.gov.rs).

The Ministry of Agriculture, Forestry and Water Management of the Republic of Serbia initiated in 2012 on the basis of a competition in keeping with the Law on Wine the formation of the Vineyard Register, which was created in cooperation with the Center for Viticulture and Winemaking from Niš. The Vineyard Register keeps a record of the areas of vineyards, their position, and the strains which are represented within these areas, as according to the Law on Wine and its bylaws all grape producers using allotments larger than 10 acres (but also smaller ones if they put their grapes on the market) are obliged to enroll in the Vineyard Register.

Also in accordance with the Law on Wine, an important database is the Winery Register, within which data is kept on producers, technological equipment that wineries possess for processing and bottling of wine, the production vessels, the raw materials and end products, the laboratory instruments, the volume of annual grape processing and wine production, the number of bottles and product sales. According to the Law on Wine and Rulebook on the Contents and Keeping of the Winery Register, it is mandatory to keep records of all the natural and legal persons, or entrepreneurs who have 10 or more acres of vineyards.

\section{Wine tourism as a stimulating business activity}

Along with wine production, wineries today also direct attention to the development of wine tourism, and vineyards give to a space a specific identity, which is important in the analysis of authenticity of tourist offers of different destinations (Štetić, Cvijanović, Šimičević, 2018). Wine tourism as a set of organized activities is based upon visits to vineyards and wineries, as well as wine-themed exhibitions and manifestations organized for recreational purposes (Johnson, 1997). Tourists join this type of travel tours, therefore, out of a desire to taste wines, to attain new knowledge about wine, to learn how best to combine food and wine, to enjoy rural areas, etc. (Milićević, Štetić, 2017). In this way, guests acquaint themselves with wine culture, a synergy is formed between the locality, gastronomy and experiences of visitors (Štetić, Cvijanović, Šimičević, 2018), and wine becomes a traditional resource forming the authenticity of a destination to the stage of forming and branding a tourist region with the aim of having it recognized in the tourist market, e.g. the regions of Bordeaux, Burgundy, Tuscany, Balaton, Rioja.

Bearing in mind that wine is the motivating factor here it is interesting to point out that moderate consumption of wine has numerous health benefits when analyzing its nutritious, hygienic, prophylactic, and medicinal value (Cindrić, 1990), with the 
important notion that wine is an integral part of a meal (Cvijanović et al., 2018) which makes the importance of wine as a food item in tourism (Pivac, 2012) specific and contributes to an increased demand in the tourist market, in terms of special interests of users of tourist services with the aim of valorizing wine tourism.

Wine tourism, education about wines and wineries are not merely a field of interest for wine connoisseurs, but also represent a segment of enriching the tourist offer in the rural spaces, and they should be viewed as such. Services are associated with wine routes, expanding their offer by including small wine producer (Štetić, Cvijanović, Šimičević, 2018). According to Pivac (2012) wine routes have as their aim representation of a region with significant wine production, with organized wine tasting. On the territory of Serbia a total of nine wine routes have been formed: Palić, Fruška Gora, Vršac, Šumadija, Smederevo-Beograd, Negotin, Župa, Niš-Kragujevac and Kosovo and Metohija (Stojković, Milićević, 2020).

Bearing in mind that research has shown that there is a linear relationship between the application of a marketing concept and actualized business profit, and that the application of a specific marketing concept enables a higher level of returns on investments (Cvijanović, 2016), this statement unambiguously points us towards the position that the choice of appropriate marketing concepts is important for wineries so they can position themselves in the market and achieve better business results.

\section{Introduction of the BEX business excellence success model}

Business excellence success models are used to assess business performance of companies, business weaknesses, as well as the negative trend that can cause business crises. One of the business performance success models is the BEX model. When creating the BEX model Belak and Aljinović-Barać (2008) were guided by application of logical selection and criteria of compatibility and sustainability in business representation, based on data from 1600 financial reports of Croatian companies which had done business on the Croatian capital market in the period between 2000 and 2008 . The model envisaged is relatively simple to use. Namely, out of a number of data and calculated indicators 14 indicators were selected, out of which 5 indicators come from the group of financial performances, 5 are structural indicators and 4 are indicators of investment efficiency of stockholders on the capital market.

The BEX model has the following structure: (Belak, Aljinović-Barać, 2008)

$$
B E X=0,388 \text { ex } 1+0,579 \text { ex } 2+0,153 \text { ex } 3+0,316 \text { ex } 4
$$

The indicators encompassed by the model are the following:

ex1 - profitability $\left(\frac{E B I T}{\text { Total Assets }}\right)$

ex2 - value creation $\left(\frac{\text { Net Business Profit }}{\text { Equity }} \times\right.$ Price $)$, 


$$
\begin{aligned}
& \text { ex3 - liquidity }\left(\frac{\text { Working Capital }}{\text { Total Assets }}\right) \\
& \text { ex4 - financial strength }\left(\frac{5 \times \text { EBITDA }}{\text { Total Liabilities }}\right) \text {. }
\end{aligned}
$$

Table 1. A summary of values for the BEX index of business excellence

\begin{tabular}{|c|c|}
\hline Bex index & Business excellence BEX ranking \\
\hline$>\mathbf{1 , 0}$ & Good company \\
\hline $\mathbf{0}-\mathbf{1}$ & Necessary business upgrades \\
\hline$<\mathbf{0}$ & Threatened existence \\
\hline
\end{tabular}

Source: Adapted from Belak, Aljinović-Barać, 2008

After calculating the obtained values of the BEX index and determining the business excellence ranking according to the categories in Table 1, it is necessary to specify the situational analysis and give a future business prognosis of the analyzed companies based on the ranking by applying the information in Table 2.

Table 2. Ranking business excellence according to the BEX index and future prognosis

\begin{tabular}{|c|c|c|}
\hline BEX index & $\begin{array}{c}\text { Business } \\
\text { excellence rang }\end{array}$ & Future forecast \\
\hline $\begin{array}{c}\text { Higher than } 6.01-4 \\
\text { years consecutively }\end{array}$ & World class & $\begin{array}{c}\text { Company operates with top results which is also to be } \\
\text { expected for the next 4 years, if management continues } \\
\text { with upgrades }\end{array}$ \\
\hline Higher than 6.01 & $\begin{array}{c}\text { World class } \\
\text { candidate }\end{array}$ & $\begin{array}{c}\text { Company has excellent operation and this is to be } \\
\text { expected over the next three years, if management } \\
\text { continues with upgrades. }\end{array}$ \\
\hline $4,01-6,00$ & Excellent & $\begin{array}{c}\text { Company has excellent operation and this is to be } \\
\text { expected over three years, if management continues } \\
\text { with upgrades }\end{array}$ \\
\hline $2,01-4,00$ & Very good & $\begin{array}{c}\text { Company has very good operation and this is to be } \\
\text { expected over the next two years if management } \\
\text { continues with upgrades. }\end{array}$ \\
\hline $1,01-2,00$ & Good & $\begin{array}{c}\text { Company has good operation and it can be expected } \\
\text { only if upgrades are made }\end{array}$ \\
\hline $0,00-1,00$ & $\begin{array}{c}\text { Limited area } \\
\text { between good and } \\
\text { poor }\end{array}$ & $\begin{array}{c}\text { Business excellence is positive, but not satisfactory. It is } \\
\text { necessary to make serious upgrades }\end{array}$ \\
\hline $\begin{array}{c}\text { Lower than } 0 \\
(\text { negative })\end{array}$ & Poor & $\begin{array}{c}\text { Existence is threatened. Urgent restructuring and } \\
\text { upgrading is needed, otherwise poor business operations } \\
\text { will continue to threaten the survival (probability is over } \\
90 \%)\end{array}$ \\
\hline
\end{tabular}

Source: Adapted from Belak, Aljinović-Barać, 2008 


\section{Materials and methods}

The aim of the research in this paper is to examine the business excellence of wineries in Serbia, wineries that deal with wine tourism (tastings, tours), via an application of the BEX model while presenting the assessment of the business success on the basis of the defined theoretical framework. The research success evaluation is based on data gathered by applying the "desk research" method from financial reports in the business of 50 commercial subjects from Serbia whose industrial classification code is $1102-$ Producing wine from grapes. The criterion in forming the sample was that the selected economic entities are engaged in the production of wine exclusively, without the production of juices and other types of alcoholic beverages (brandy, cognac), as well as that the activities of wine tourism within their business are represented. During the Wine Fair in Belgrade in February 2020, the exhibitors/wineries were asked whether they organized wine tourism activities and the obtained data were implemented in the process of forming a sample of wineries which are the subject of analysis in this paper. Financial reports for the business years 2017 and 2018 have been accessed at the website of the Agency for Commercial Registers (APR). The financial reports accessed formed a database of key data/indicators, based on which a calculation of the BEX model of business excellence was then done. The results obtained were explicated by way of applying the comparative method and correlation method, and individual values presented in the form of tables.

At the same time, an analysis of the website content of 50 sampled wineries was done to see if the wineries promote wine tourism activities online. Then, a comparison and statistical analysis of the correlation (ANOVA) of the obtained BEX values index and the existence of promotional activities of wine tourism on web pages of the analyzed sample of wineries were performed.

\section{Research results}

Based on the collected data, after calculating business excellence by applying the BEX model, Table 3 was formed within which is given a summary of values obtained for the BEX index of business excellence of winemakers for the business years 2017 and 2018, individually, per each company from the sample.

Table 3. Summary of values for the BEX index of business excellence of wineries individually for the years 2017 and 2018

\begin{tabular}{|c|c|c|c|c|}
\hline Winery & BEX17 & BEX17 ranking & BEX18 & BEX18 ranking \\
\hline $\mathbf{1}$ & 2.3401985 & Very good & 1.9973244 & Good \\
\hline $\mathbf{2}$ & 0.1525071 & Bordering area & -0.2919228 & Poor \\
\hline $\mathbf{3}$ & 1.9230744 & Good & 0.2133787 & Bordering area \\
\hline $\mathbf{4}$ & 1.3939688 & Good & 1.9083714 & Good \\
\hline $\mathbf{5}$ & 2.6208003 & Very good & 0.6893914 & Bordering area \\
\hline $\mathbf{6}$ & 1.0844546 & Good & 2.6694332 & Very good \\
\hline
\end{tabular}




\begin{tabular}{|c|c|c|c|c|}
\hline Winery & BEX17 & BEX17 ranking & BEX18 & BEX18 ranking \\
\hline 7 & -1.4277721 & Poor & -1.3070359 & Poor \\
\hline 8 & 6.9108855 & World class candidate & 0.342561 & Bordering area \\
\hline 9 & -0.1030928 & Poor & -0.1610141 & Poor \\
\hline 10 & 0.0236522 & Bordering area & -0.0230706 & Poor \\
\hline 11 & 0.7957732 & Bordering area & 0.4242903 & Bordering area \\
\hline 12 & 1.669929 & Good & 1.1937852 & Good \\
\hline 13 & 1.8564792 & Good & 2.3167442 & Very good \\
\hline 14 & 2.2052865 & Very good & 2.0523132 & Very good \\
\hline 15 & 0.0562429 & Bordering area & 0.0566933 & Bordering area \\
\hline 16 & 2.6355599 & Very good & 2.8355651 & Very good \\
\hline 17 & 1.2950491 & Good & 1.2443799 & Good \\
\hline 18 & 9.7543126 & World class candidate & 9.9979794 & World class candidate \\
\hline 19 & 1.0647056 & Good & 0.2815473 & Bordering area \\
\hline 20 & 2.2438761 & Very good & 2.969169 & Very good \\
\hline 21 & 6.3012746 & World class candidate & 1.9276741 & Good \\
\hline 22 & 0 & No rating & 0 & No rating \\
\hline 23 & 0 & No rating & 20.872309 & World class candidate \\
\hline 24 & 0.0031246 & Bordering area & 0.2965015 & Bordering area \\
\hline 25 & 8.9149023 & World class candidate & 1.8834388 & Good \\
\hline 26 & 3.1654317 & Very good & 2.5999209 & Very good \\
\hline 27 & 0 & No rating & 0 & No rating \\
\hline 28 & 1.2409572 & Good & 0.6539004 & Bordering area \\
\hline 29 & 0 & No rating & 0 & No rating \\
\hline 30 & 35.067258 & World class candidate & -0.0017223 & Poor \\
\hline 31 & 3.5036087 & Very good & 1.7071471 & Good \\
\hline 32 & 0.7163724 & Bordering area & 0.6063955 & Bordering area \\
\hline 33 & 0.657903 & Bordering area & 0.1548 & Bordering area \\
\hline 34 & 0.138443 & Bordering area & 0.4684103 & Bordering area \\
\hline 35 & 0 & No rating & 0 & No rating \\
\hline 36 & 3.1810438 & Very good & 0.7696727 & Bordering area \\
\hline 37 & 0.1211009 & Bordering area & -0.0582702 & Poor \\
\hline 38 & -0.0052605 & Poor & -0.0166373 & Poor \\
\hline 39 & 0.4170116 & Bordering area & 0.8558957 & Bordering area \\
\hline 40 & 0 & No rating & 0 & No rating \\
\hline 41 & 0.5361253 & Bordering area & 0.4772747 & Bordering area \\
\hline 42 & 0.6156597 & Bordering area & 5.041973 & Excellent \\
\hline 43 & 0.6385622 & Bordering area & 0.5444125 & Bordering area \\
\hline 44 & 28.8549 & World class candidate & -0.0227508 & Poor \\
\hline 45 & -18.967693 & Poor & 0 & No rating \\
\hline 46 & 0.1243977 & Bordering area & -0.1672299 & Poor \\
\hline 47 & 1.3579661 & Good & 2.9941766 & Very good \\
\hline 48 & 0 & No rating & 0 & No rating \\
\hline 49 & 4.9165456 & Excellent & 3.617173 & Very good \\
\hline 50 & 0.7639495 & Bordering area & 0.28924 & Bordering area \\
\hline
\end{tabular}

Source: Calculation by the authors 
Figure 2. Graph of BEX index ranking fluctuation for years 2017 and 2018 per companies in the sample

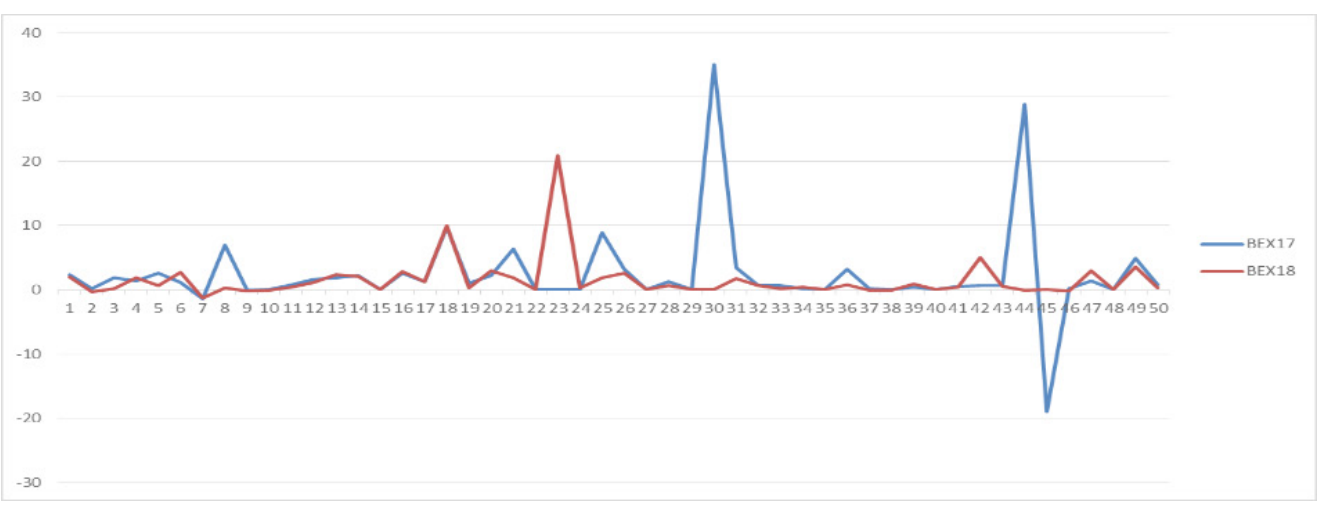

Source: Calculation by the authors

The task was to complete a unified analysis of the sample of companies producing wine in Serbia and the results obtained are given in Table 4.

Table 4. Results of the BEX index of business excellence calculated together for the sample of wineries

\begin{tabular}{|c|c|c|}
\hline & $\mathbf{2 0 1 7}$ & $\mathbf{2 0 1 8}$ \\
\hline ex1 profitability & 0.04089 & 0.03902 \\
\hline ex2 creating value & 4.39756 & 2.40437 \\
\hline ex3 liquidity & -0.96061 & -0.10750 \\
\hline ex4 financial strength & 1.84460 & 0.87502 \\
\hline BEX & $\mathbf{2 . 6 6 5 9 5}$ & $\mathbf{1 . 5 0 9 8 4}$ \\
\hline Rang BEX & Very good & Good \\
\hline
\end{tabular}

Source: Calculation by the authors

The results obtained enable us to perceive changes that occurred in the business of wineries in the business years 2017 and 2018, based on an analysis of the data from financial reports. Namely, in the analysis of the values for ranking in the BEX model for the year 2017 the value of the BEX index obtained was 2.66595, and in accordance with the data on the business success of analyzed companies the business excellence ranking is among companies with very good business, with the recommendation for future business to have the management try to keep this level of business while striving to advance business processes, and thus also the indicator values for the following years.

Analyzing the values for BEX model rankings for the year 2018 of the sample of companies producing wine, the obtained value of the index 1.50984 indicates that the business of companies is classified in the category of good values. Bearing in mind the obtained result, the suggestion is that advancement in business if desirable with the aim of maintaining or increasing the level of business excellence. 
Observing and analyzing the values in financial reports of the analyzed companies it was noticed that several companies have investment activities in their business, which are mostly realized through borrowed means. Some of them had an increase in longterm obligations, and even business year net results in the form of Net Losses. Such values have, in a number of analyzed companies, caused a business excellence ranking in the Bordering area. At the same time, a smaller number of companies have a business excellence ranking at the Excellent and World class levels, and their business and values of indicators can serve as excellent examples of doing business.

According to Njegovan (2016) financial liquidity is a necessity from the aspect of doing business and survival of any agricultural estate, and bearing in mind the seasonal character of the business, non-simultaneous investments into production and problems with collecting payments it becomes clear that financial liquidity is achieved by going into debt or by diversifying business activities. The problem of liquidity in wineries occurs due to the lack of continuous sales and collection of receivables. Namely, wineries have certain problems with wine placement: a) due to the large amount of foreign wines with low selling prices on the market, b) due to the still low awareness of the population for wine consumption, c) still undeveloped export of Serbian wines, e) monopoly conditions of sales channels ie. conditionality of product placement in retail chains that often expect a long deadline to settle their obligations. This situation causes a limited inflow of funds in continuity, which causes the impossibility of settling fixed costs in regular operations, as well as settling receivables.

Analyzing the structure of the BEX model of the entire sample of wineries in Table 4 it is possible to perceive a major problem with liquidity(negative values of liquidity indicators in 2017 at -0.96061 , and in 2018 at -0.10750), and this is confirmed in data on the indebtedness of companies. At the same time, the values of profitability and financial power indicators are in the rank of the bordering area, and the indicators pointing towards the potential to create value are ranked among very good results (in 2017 at 4.397756 , and in 2018 at 2.40437). One of the reasons for middling business results can certainly be found in the natural resources upon which the business of this commercial branch is based, and that is the amount of grape yield for each year/season, which also determines the amount of wine produced.

Table 5. Analysis of BEX index fluctuations in sampled wineries and amounts of wine produced in 2017 and 2018 in Serbia

\begin{tabular}{|c|c|c|}
\hline & $\mathbf{2 0 1 7}$ & $\mathbf{2 0 1 8}$ \\
\hline BEX Index & 2.66595 & 1.50984 \\
\hline Vine product (ha) & 736,000 & 665,000 \\
\hline
\end{tabular}

Source: Calculation by the authors

Therefore, is we take into account the obtained values of the BEX index of business excellence for the years 2017 and 2018 and the presented data on amounts of produced wine in the analyzed years it is possible to notice a correlation between the values of amount of produced wine and indicators of business excellence in the business of sampled wineries in Serbia. 
After the analysis of BEX index, a "desk research" analysis of 50 sampled wineries' websites was performed in order to detect information on the promotion of wine tourism activities (tasting, tour of wineries). Of all the analyzed samples, 20 wineries promote activities included in wine tourism on their websites. Table 6 provides a comparative overview of the $\mathrm{BEX}$ index rank and information on wine tourism on the wineries' websites.

Table 6. Comparative overview of the BEX index rank and information on wine tourism on the wineries' website

\begin{tabular}{|c|c|c|c|c|c|c|}
\hline Winery & BEX17 & $\begin{array}{c}\text { Rank } \\
\text { BEX17 }\end{array}$ & $\begin{array}{c}\text { wine tourism } \\
\text { promotion } \\
\text { on website }\end{array}$ & BEX18 & Rank BEX18 & $\begin{array}{c}\text { wine } \\
\text { tourism } \\
\text { promotion } \\
\text { on website }\end{array}$ \\
\hline 1 & 2.3401985 & Very good & yes & 1.9973244 & Good & yes \\
\hline 2 & 0.1525071 & $\begin{array}{c}\text { Bordering } \\
\text { area }\end{array}$ & no & -0.2919228 & Poor & no \\
\hline 3 & 1.9230744 & Good & yes & 0.2133787 & $\begin{array}{c}\text { Bordering } \\
\text { area }\end{array}$ & yes \\
\hline 4 & 1.3939688 & Good & no & 1.9083714 & Good & no \\
\hline 5 & 2.6208003 & Very good & no & 0.6893914 & $\begin{array}{c}\text { Bordering } \\
\text { area }\end{array}$ & no \\
\hline 6 & 1.0844546 & Good & yes & 2.6694332 & Very good & yes \\
\hline 7 & -1.4277721 & Poor & no & -1.3070359 & Poor & no \\
\hline 8 & 6.9108855 & $\begin{array}{c}\text { World class } \\
\text { candidate }\end{array}$ & no & 0.342561 & $\begin{array}{c}\text { Bordering } \\
\text { area }\end{array}$ & no \\
\hline 9 & -0.1030928 & Poor & no & -0.1610141 & Poor & no \\
\hline 10 & 0.0236522 & $\begin{array}{c}\text { Bordering } \\
\text { area }\end{array}$ & yes & -0.0230706 & Poor & yes \\
\hline 11 & 0.7957732 & $\begin{array}{c}\text { Bordering } \\
\text { area }\end{array}$ & no & 0.4242903 & $\begin{array}{c}\text { Bordering } \\
\text { area }\end{array}$ & no \\
\hline 12 & 1.669929 & Good & no & 1.1937852 & Good & no \\
\hline 13 & 1.8564792 & Good & yes & 2.3167442 & Very good & yes \\
\hline 14 & 2.2052865 & Very good & no & 2.0523132 & Very good & no \\
\hline 15 & 0.0562429 & $\begin{array}{c}\text { Bordering } \\
\text { area }\end{array}$ & yes & 0.0566933 & $\begin{array}{c}\text { Bordering } \\
\text { area }\end{array}$ & yes \\
\hline 16 & 2.6355599 & Very good & yes & 2.8355651 & Very good & yes \\
\hline 17 & 1.2950491 & Good & no & 1.2443799 & Good & no \\
\hline 18 & 9.7543126 & $\begin{array}{c}\text { World class } \\
\text { candidate }\end{array}$ & no & 9.9979794 & $\begin{array}{l}\text { World class } \\
\text { candidate }\end{array}$ & no \\
\hline 19 & 1.0647056 & Good & yes & 0.2815473 & $\begin{array}{c}\text { Bordering } \\
\text { area }\end{array}$ & yes \\
\hline 20 & 2.2438761 & Very good & no & 2.969169 & Very good & no \\
\hline 21 & 6.3012746 & $\begin{array}{c}\text { World class } \\
\text { candidate }\end{array}$ & no & 1.9276741 & Good & no \\
\hline 22 & 0 & No rating & no & 0 & No rating & no \\
\hline 23 & 0 & No rating & no & 20.872309 & $\begin{array}{l}\text { World class } \\
\text { candidate }\end{array}$ & no \\
\hline
\end{tabular}




\begin{tabular}{|c|c|c|c|c|c|c|}
\hline Winery & BEX17 & $\begin{array}{c}\text { Rank } \\
\text { BEX17 }\end{array}$ & $\begin{array}{c}\text { wine tourism } \\
\text { promotion } \\
\text { on website }\end{array}$ & BEX18 & Rank BEX18 & $\begin{array}{c}\text { wine } \\
\text { tourism } \\
\text { promotion } \\
\text { on website }\end{array}$ \\
\hline 24 & 0.0031246 & $\begin{array}{c}\text { Bordering } \\
\text { area }\end{array}$ & no & 0.2965015 & $\begin{array}{c}\text { Bordering } \\
\text { area }\end{array}$ & no \\
\hline 25 & 8.9149023 & $\begin{array}{c}\text { World class } \\
\text { candidate }\end{array}$ & yes & 1.8834388 & Good & yes \\
\hline 26 & 3.1654317 & Very good & yes & 2.5999209 & Very good & yes \\
\hline 27 & 0 & No rating & yes & 0 & No rating & yes \\
\hline 28 & 1.2409572 & Good & yes & 0.6539004 & $\begin{array}{c}\text { Bordering } \\
\text { area }\end{array}$ & yes \\
\hline 29 & 0 & No rating & yes & 0 & No rating & yes \\
\hline 30 & 35.067258 & $\begin{array}{l}\text { World class } \\
\text { candidate }\end{array}$ & no & -0.0017223 & Poor & no \\
\hline 31 & 3.5036087 & Very good & no & 1.7071471 & Good & no \\
\hline 32 & 0.7163724 & $\begin{array}{c}\text { Bordering } \\
\text { area }\end{array}$ & yes & 0.6063955 & $\begin{array}{c}\text { Bordering } \\
\text { area }\end{array}$ & yes \\
\hline 33 & 0.657903 & $\begin{array}{c}\text { Bordering } \\
\text { area }\end{array}$ & no & 0.1548 & $\begin{array}{c}\text { Bordering } \\
\text { area }\end{array}$ & no \\
\hline 34 & 0.138443 & $\begin{array}{c}\text { Bordering } \\
\text { area }\end{array}$ & yes & 0.4684103 & $\begin{array}{c}\text { Bordering } \\
\text { area }\end{array}$ & yes \\
\hline 35 & 0 & No rating & no & 0 & No rating & no \\
\hline 36 & 3.1810438 & Very good & yes & 0.7696727 & $\begin{array}{c}\text { Bordering } \\
\text { area }\end{array}$ & yes \\
\hline 37 & 0.1211009 & $\begin{array}{c}\text { Bordering } \\
\text { area }\end{array}$ & no & -0.0582702 & Poor & no \\
\hline 38 & -0.0052605 & Poor & no & -0.0166373 & Poor & no \\
\hline 39 & 0.4170116 & $\begin{array}{l}\text { Bordering } \\
\text { area }\end{array}$ & no & 0.8558957 & $\begin{array}{c}\text { Bordering } \\
\text { area }\end{array}$ & no \\
\hline 40 & 0 & No rating & no & 0 & No rating & no \\
\hline 41 & 0.5361253 & $\begin{array}{l}\text { Bordering } \\
\text { area }\end{array}$ & yes & 0.4772747 & $\begin{array}{c}\text { Bordering } \\
\text { area }\end{array}$ & yes \\
\hline 42 & 0.6156597 & $\begin{array}{c}\text { Bordering } \\
\text { area }\end{array}$ & no & 5.041973 & Excellent & no \\
\hline 43 & 0.6385622 & $\begin{array}{c}\text { Bordering } \\
\text { area }\end{array}$ & no & 0.5444125 & $\begin{array}{c}\text { Bordering } \\
\text { area }\end{array}$ & no \\
\hline 44 & 28.8549 & $\begin{array}{l}\text { World class } \\
\text { candidate }\end{array}$ & yes & -0.0227508 & Poor & yes \\
\hline 45 & -18.967693 & Poor & no & 0 & No rating & no \\
\hline 46 & 0.1243977 & $\begin{array}{l}\text { Bordering } \\
\text { area }\end{array}$ & no & -0.1672299 & Poor & no \\
\hline 47 & 1.3579661 & Good & no & 2.9941766 & Very good & no \\
\hline 48 & 0 & No rating & yes & 0 & No rating & yes \\
\hline 49 & 4.9165456 & Excellent & no & 3.617173 & Very good & no \\
\hline 50 & 0.7639495 & $\begin{array}{l}\text { Bordering } \\
\text { area }\end{array}$ & no & 0.28924 & $\begin{array}{c}\text { Bordering } \\
\text { area }\end{array}$ & no \\
\hline
\end{tabular}

Source: Calculation by the authors 
Data on business success ranking and promotion of wine tourism on the wineries' websites were processed through the statistical package SPSS 22.0 by calculating the correlation coefficient and the ANOVA statistical method. Using the obtained results, the situational analysis of the impact of wine tourism activities promotion and business success was considered.

Within the value analysis, BEX model is defined as a dependent variable, and an independent variable is the data whether the information of wine tourism promotion is posted on the wineries' websites. When testing the existence of the mentioned information on wine tourism activities on the websites for 2018, the obtained results indicate that the value of $\mathrm{R}$ is 0.134 , which means that it is an extremely small correlation (Table 7 ).

Table 7. Model Summary for BEX model 2018

\begin{tabular}{|c|c|c|c|c|}
\hline Model & $\mathrm{R}$ & $\mathrm{R}$ Square & $\begin{array}{c}\text { Adjusted R } \\
\text { Square }\end{array}$ & $\begin{array}{c}\text { Std. Error of } \\
\text { the Estimate }\end{array}$ \\
\hline 1 & $.134^{\mathrm{a}}$ & .018 & -.002 & 3.31696 \\
\hline a. Predictors: (Constant), VAR00001 \\
\hline
\end{tabular}

Source: Autors adapted from statistical package SPSS 22.0

Table 8. ANOVA BEX model 2018 and information about wine tourism promotion on the wineries' websites

\begin{tabular}{|c|c|c|c|c|c|}
\hline Model & $\begin{array}{c}\text { Sum of } \\
\text { Squares }\end{array}$ & df & Mean Square & F & Sig. \\
\hline Regression & 9.682 & 1 & 9.682 & .880 & $.353^{\text {b }}$ \\
\hline Residual & 528.106 & 48 & 11.002 & & \\
\hline Total & 537.788 & 49 & & & \\
\hline \\
a. Dependent Variable: VAR00003 \\
b. Predictors: (Constant), VAR00001 \\
\hline
\end{tabular}

Source: Autors adapted from statistical package SPSS 22.0

Also, the outcome of the F test is not significant (Table 8) because Sig is 0.880 (more than 0.05 ), so we can conclude that the data from the websites on activities related to wine tourism realized in the analyzed wineries does not affect business success in 2018.

Values for 2017 indicate that the value of $\mathrm{R}$ is 0.069 , which means that there is no correlation (Table 9). The F-test is not significant because Sig is 0.229 (Table 10).

Table 9. Model Summary for BEX index 2017

\begin{tabular}{|c|c|c|c|c|}
\hline Model & $\mathrm{R}$ & R Square & $\begin{array}{c}\text { Adjusted R } \\
\text { Square }\end{array}$ & $\begin{array}{c}\text { Std. Error of } \\
\text { the Estimate }\end{array}$ \\
\hline 1 & $.069^{\mathrm{a}}$ & .005 & -.016 & 7.20413 \\
\hline a. Predictors: (Constant), VAR00001 \\
\hline
\end{tabular}

Source: Autors adapted from statistical package SPSS 22.0 
Table 10. ANOVA BEX model 2017 and information about wine tourism promotion on the wineries' websites

\begin{tabular}{|c|c|c|c|c|c|}
\hline Model & $\begin{array}{c}\text { Sum of } \\
\text { Squares }\end{array}$ & df & Mean Square & F & Sig. \\
\hline Regression & 11.908 & 1 & 11.908 & .229 & $.634^{\text {b }}$ \\
\hline Residual & 2491.175 & 48 & 51.899 & & \\
\hline Total & 2503.083 & 49 & & & \\
\hline \\
a. Dependent Variable: VAR00002 \\
b. Predictors: (Constant), VAR00001 \\
\hline
\end{tabular}

Source: Autors adapted from statistical package SPSS 22.0

Bearing in mind that business success of some analyzed wineries is in the World class rank without promoting wine tourism activities on the website, and that the results of ANOVA analysis indicate no correlation, the research thesis that wineries which promote wine tourism activities on their websites have a better rank of business performance in line with the values of BEX model is not supported.

\section{Conclusion}

Two criteria were used when forming the sample of wineries whose business results were analyzed, that wineries are engaged in wine production as their only final product (activity code 1102 - Production of wine from grapes), and that they are engaged in wine tourism, which is confirmed by direct contact with wineries' representatives during the Wine Fair in Belgrade.

Bearing in mind the obtained results of the BEX index after processing and analysis of the business data of wineries, the suggestion is that advancement in business is desirable in order to maintain or increase the degree of business success. In accordance with the decrease in produced amounts of wine it is possible to emphasize the constantly high expenses of investing into and maintaining vineyards, as well as the equipment and technological processes in wine production, which characterize this commercial branch. Simultaneously, it is very significant to point out the seasonal nature of the business, in terms of grape processing and winemaking, and these facts contribute to an overall encumbrance in planning and conducting business successfully.

Therefore, analyzing the obtained data and information and taking into account the fragmentation of allotments i.e. the large number of small producers, it is necessary to point out the importance of adopting the Strategy for the Development of Viticulture and Winemaking, as a significant document forming the basis for the development of the mentioned commercial branch. It is important to point out the potentials in the development of wine tourism on the territory of Serbia bearing in mind the current international thematic tourist product i.e. the cultural route of the European Council - The Roman Emperors and Danube Wine Route (since 2015), the wine routes included in this international project, as well as the other vineyards throughout Serbia. In accordance with the potentials which Serbia possesses, excellent spatial and climate conditions for successful viticultural endeavors, the suggestion is that autochthonous brands should be strengthened from the aspect of 
increasing the market share and export, and some research indicates that consumers see the wine brand, and not the price tag, as the decisive factor in their choice (Kuzmanović, Makajić-Nikolić, 2020).

Considering the results obtained after research and analysis, it was noticed that some wineries in the sample have a World class rank of business success and that they implement wine tourism activities without promoting them on their websites.

These wineries generate excellent business revenues from wine production/sales, but also from tourist visits in accordance with wine tourism activities as a result of the quality and trust that wine consumers have. Tradition and quality remain recognizable when it comes to choosing wine tourists.

The results of this research have a scientific and practical contribution. The scientific contribution is reflected in the unification and application of the results of research conducted in the process of analysis of the promotion of wine tourism activities on the websites of wineries. A significant scientific contribution is the analysis that was conducted for the first time in the assessment of business success of wineries in Serbia. Namely, bearing in mind that wineries are in a state of constant pressure in the processes of adapting to market conditions, minimizing costs and increasing profitability, the BEX model can predict difficulties in winery operations, and monitoring the value of indicators can avoid potential business risks. The practical contribution is reflected in the possibility of using the research results by wineries in Serbia that deal with wine tourism, but do not promote it on their websites. In addition, the practical contribution is reflected in the possibility of using the research results in order to create a Strategy for the development of wine tourism in Serbia.

Future research could analyze whether additional wine tourism promotional activities on the wineries' websites contribute to the increase in the number of visitors, as well as to the improvement of business results. In this way, winemakers would reach their products' buyers faster at the place of production and thus minimize the time of sale and charging for wine. What is more, a new research could be conducted on the business performance of wineries that do not develop wine tourism. The obtained results could be compared with the BEX index results of wineries that develop wine tourism so that new strategic decisions could be made.

\section{Conflict of interests}

The authors declare no conflict of interest.

\section{References}

1. Alihodžić, A.\& Džafić, J. (2012). Models for the evaluation of business excellence in capital market of Bosnia and Hercegovina. Singidunum Journal, 9(I):9-15. doi: $10.5937 /$ sjas $1201009 \mathrm{~A}$

2. Avramov, L. (2010). Wine growing, Belgrade [in Serbian: Аврамов, Л. (2010). Виноградарство, Завод за уџбенике, Београд] 
3. Belak, V., Aljinović Barać, Ž. \& Vuko, T. (2011). Stocks Selection in Capital Markets Crisis: Multi-criteria Approach, International Journal of Economics and Business Research, 3(1): 60-71

4. Belak, V. \& Aljinović Barać, Ž. (2008). Capital market secrets. Belak Excellens, Zagreb.[in Croatian: Belak, V. \& Aljinović Barać, Ž. (2008). Tajne tržišta kapitala]

5. Berk, J., DeMarzo, P. \& Harford, J. (2012). Fundamentals of Corporate Finance. Prentice Hall, London

6. Bubić, J. \& Hajnrih, J. (2012) The analysis business performance of agricultural enterprises in Vojvodina during the current crises, Economics of Agriculture 2/12:183-194

7. Cindrić, P. (1990). Sorte vinove loze. Nolit, Beograd

8. Cvijanović, D., Vujko, A. \& Gajić, T. (2018). Farm Houses (Salaši) as a Gastronomic Potential of Vojvodina in the Function of Tourist Offer. KNOWLEDGE International Journal Invited Scientific Papers, 21.1: 13-16

9. Cvijanović, D. (2016). Marketing in Tourism.Faculty of Hotel Management and Tourism in Vrnjačka Banja, University of Kragujevac.[in Serbian: Цвијановић, Д. (2016). Маркетинг у туризму, Факултет за хотелијерство и туризам у Врњачкој Бањи, Универзитет у Крагујевцу]

10. Darnay, S. (2016).Quality of Landscape and Sustainability Benefit to Wine Tourism: Contexts and Commitments in: Peris Ortiz, M. et al,. (2016). Wine and Tourism, Springier

11. Despotović I., (2012). Wine. [in Serbian: Despotović I. (2012). Vino. Imperija knjiga, Kragujevac]

12. Ivanišević, D., Jakšić, D. \& Korać, N. (2015). Viticultural Atlas. Statistical Office of the Republic of Serbia, Belgrade. [in Serbian: Иванишевић, Д., Јакшић, Д. \& Кораћ, Н. (2015). Виноградарски атлас, Републички завод за статистику]

13. Jakšić, D., Bradić, I., Beader, M., Ristić, M.,Popović, D.,Mošić, I.\& Dodok I.(2019). Viticulture and winemaking of Serbia. Center of Viticulture and winemaking, Niš. [in Serbian: Јакшић, Д., Брадић, И., Беадер, М., Ристић, М., Поповић, Д., Мошић, И. \& Додок, И. (2019). Виноградарство и винарство Србије, Центар за виноградарство и винарство]

14. Jakšić, D., Ivanišević, D., Đokić, V.\& Brbaklić Tepavac, M. (2015).Wine Atlas. Statistical Office of the Republic of Serbia, Belgrade. [in Serbian: Јакшић, Д., Иванишевић, Д., Ђокић, В. \& Брбаклић Тепавац, М. (2015). Вински атлас, Републички завод за статистику Републике Србије]

15. Johnson, G. (1997). Surveying Wine Tourism in New Zeland. Proceedings of the

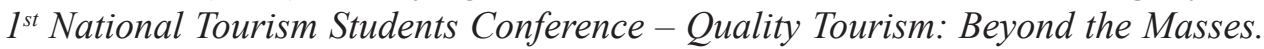
Tourism Club; 61-66.

16. Knežević, G., Stanišić, N. \& Mizdraković, V. (2014). Predictive ability of the BEX model: The case of foreign Investors in Serbia from 2008 to 2012, TEME, 4(1): $1475-1488$. 
17. Kuzmanović, M. \& Makajić-Nikolić, D. (2020). Heterogeneity of Serbian consumers preferences for local wines:Discrete choice analysis, Economics of Agriculture 1/20: 37-54. doi:10.5937/ekoPolj2001037K

18. Milićević, S. \& Štetić, S. (2017). Tourism Management. Faculty of Hotel Management and Tourism in Vrnjačka Banja, University of Kragujevac, Vrnjačka Banja.[in Serbian:Милићевић, С. \& Штетић, С. (2017). Менаџмент у туризму, Факултет за хотелијерство и туризам у Врњачкој Бањи, Универзитет у Крагујевцу, Врњачка Бања]

19. Njegovan, Z. (2016). Economics of Tourism and Rural Tourism. Faculty of Agriculture, University of Novi Sad. [in Serbian:Његован, 3. (2016). Економика туризма и сеоског туризма. Пољопривредни факултет, Нови Сад]

20. Ordinance on incentives for investments in processing and marketing of-agricultural and food products in the wine production sector (2020). Official Gazette of the Republic of Serbia, No. 87/2020. [in Serbian: Pravilnik o podsticajima za investicije $\mathrm{u}$ preradu i marketing poljoprivrednih i prehrambenih proizvoda $\mathrm{u}$ sektoru proizvodnje vina. (2020). Сл. гласник PC 87/2020]. Retrieved from: http://uap. gov.rs/pravilnici/mere-ruralnog-razvoja/pravilnik-o-podsticajima-za-investicijeu-preradu-i-marketing-poljoprivrednih-i-prehrambenih-proizvoda-u-sektoruproizvodnje-vina/?lang=lat (September 05, 2020)

21. Pavlović, S. (2007). Remnants of Sirmium are located under Sremska Mitrovica. Earth and People No 57, Serbian Geographical Society, Belgrade. [in Serbian: Павловић, С. (2007). Остаци Сирмиума се налазе испод Сремске Митровице. Земља и људи бр.57, Српско географско друштво, Београд]

22. Pivac, T. (2012). Wine Tourism of Vojvodina.University of Novi Sad.[in Serbian: Пивац, Т. (2012). Вински туризам у Војводини. Универзитет у Новом Саду]

23. Popescu, G. H., Nicoale, I., Nica, E., Vasile, A. J., \& Andreea, I. R. (2017). The influence of land-use change paradigm on Romania's agro-food trade competitiveness-An overview. Land Use Policy, 61, 293-301. doi: https://doi. org/10.1016/j.landusepol.2016.10.032

24. Rajin, D., Milenković, D. \& Radojević, T. (2016). Bankruptcy prediction models in the Serbian Agricultural Sector, Economics of Agriculture 1/16:89-105. doi:10.5937/ekoPolj1601089R

25. Regester, M. \& Larkin, J. (1997). Risk Issues and Crisis Management, Kogan, London

26. Rulebook on the content and keeping of the wine register. Official Gazette of the Republic of Serbia, No. 67/2011 \& 61/2017, Belgrade [in Serbian: Правилник о садржини и вођењу винарског регистра, Сл. гласник PC 67/2017,61/2017]. Retrieved from http://extwprlegs1.fao.org/docs/pdf/srb153782.pdf (May 15, 2020)

27. Statistical Yearbook 2018. Statistical Office of the Republic of Serbia, Belgrade. [in Serbian: Статистички годишњак 2018, Републички завод за статистику Републике Србије] 
28. Stanišić, M., Radović, N. \& Nikolić, J. (2017). Business success analysis in the hotel industry, 4th International Scientific Conference FINIZ 2017, Singidunum University, Belgrade, Paper presented at FINIZ 2017 - Challenges in modern corporate governance.doi:10.15308/finiz-2017-14-17.Available at http://portal. finiz.singidunum.ac.rs/paper/42513

29. Strategy of agriculture and rural development of the Republic of Serbia for the period 2014-2024 year. Official Gazette of the Republic of Serbia, No. 85/2014, Belgrade. [in Serbian:Стратегија пољопривреде и руралног развоја Републике Србије за период 2014-2024. године, Сл.гласник РС 85/2014.]. Available at http://uap.gov.rs/wp-content/themes/uap/STRATEGIJA\%202014-2020\%20.pdf

30. Stojković, J. \& Milićević, S. (2020). SWOT analysis of wine tourism development opportunities in the Trstenik vineyard district. Hotel and Tourism Management, 8(1), 59-67. doi: 10.5937/menhottur2001059S

31. Štetić, S., Cvijanović, D. \& Šimičević, D. (2014). Special forms of tourism in the Danube region of Serbia. Institute of Agricultural Economics, Belgrade. [in Serbian: Штетић, С., Цвијановић, Д. \& Шимичевић, Д. (2014). Посебни облици туризма дунавског региона Србије, Институт за економику пољопривреде]

32. The Agency for Commercial Registers. Retreived from https:/www.apr.gov.rs (September 17, 2019)

33. The International Organization of Vine and Wine. Retreived from https://www.oiv. int/en/statistiques (May 15, 2020)

34. The Statistical Office of the Republic of Serbia. Retreived from https://www.rzs. gov.rs (May 18, 2020)

35. Tourism Development Strategy of the Republic of Serbia the period 2016-2025 year. [in Serbian: Стратегија развоја туризма Републике Србије за период 2016-2025. године]. Available at: https://mtt.gov.rs/download/3/TOURISM\%20 DEVELOPMENT\%20STRATEGY\%20OF\%20RS\%202016-2025.pdf

36. Vlahović, B., Puškarić, A. \& Užar, D. (2017). Modern trends in the Wine Market. Faculty of Agriculture, University of Novi Sad. [in Serbian: Влаховић, Б., Пушкарић, А. \& Ужар, Д. (2017). Савремени трендови на тржишту вина, Пољопривредни факултет, Универзитета у Новом Саду]

37. Vlahović, B., Tomić, D.\& Puškarić, A. (2008). Wine production in Republic of Serbia. Economics of Agriculture 3/2008:277-288. [in Serbian: Влаховић, Б., Томић, Д.\& Пушкарић, А. (2008). Производња вина у Републици Србији, Економика пољопривреде 3/2008:277-288]

38. Vasile,A. J., Popescu, C., Ion, R.A., \& Dobre, I. (2015). From conventional to organic in Romanian agriculture-Impact assessment of a land use changing paradigm. Land Use Policy, 46, 258-266. doi: https://doi.org/10.1016/j.landusepol.2015.02.012 
39. Vasile, A. J., Mihai, M., \& Mirela, P. (2017). Transformations of the Romanian agricultural paradigm under domestic economic policy reforms: An analysis during 1960-2011. Land Use Policy, 67, 288-297, doi: https://doi.org/10.1016/j. landusepol.2017.06.008

40. Vasilescu, I., Cicea, C., Popescu, G., \& Andrei, J. (2010). A new methodology for improving the allocation of crops cost production in Romania. Journal of Food, Agriculture and Environment, 8(2), 839-842.

41. Wine Law.Official Gazette of the Republic of Serbia, No. 41/09 \& 93/12, Belgrade[in Serbian: Закон о вину, Сл. гласник РС, бр. 41/09 \& 93/12]. Available at http:// www.minpolj.gov.rs/download/zakon-o-vinu-2/?script=lat 